\title{
HUBUNGAN PANJANG DAN BERAT IKAN NILA (Oreochromis niloticus) DALAM MEDIA PEMBESARAN DENGAN PENAMBAHAN ENZIM EZ-PLUS(SKALA LABORATORIUM)
}

\author{
Length - Weight Relation of Tilapia (Orechromis niloticus) in Growing Medium with Addition Enzyme EZ-plus \\ (Laboratory Scale)
}

\section{Muhammad Dwi Hudoyo Swarto, Haeruddin*),Siti Rudiyanti}

\author{
Program Studi Manajemen Sumberdaya Perairan \\ Departemen Sumberdaya Akuatik Fakultas Perikanan dan Ilmu Kelautan, Universitas Diponegoro \\ Jl. Prof. Soedharto, SH, Tembalang, Semarang, Jawa Tengah-50275 \\ Email : Dwihudoyoswarto@gmail.com
}

\begin{abstract}
ABSTRAK
Salah satu upaya untuk mengoptimalkan pertumbuhan panjang dan berat dalam kegiatan pembesaran ikan Nila adalah memperbaiki daya cerna dengan cara pemberian enzim EZ-plus ke dalam pakan ikan. Penelitian ini bertujuan untuk mengetahui pertumbuhan panjang dan bobot ikan Nila (Oreochromis niloticus) pada berbagai konsentrasi enzim yang ditambahkan pada pakan, serta keeratan hubungan antara pakan yang telah diberi enzim dengan pertambahan panjang total dan bobot ikan. Penelitian ini dilaksanakan selama 35 hari yaitu pada bulan Mei-Juni 2017. Metode dalam penelitian ini menggunakan eksperimental dengan Rancangan Acak Lengkap (RAL) dengan 5 perlakuan sebagai berikut: kontrol, L (0,0125\%), M (0,025\%), N (0,05\%) dan O $(0,075 \%)$. Pemberian pakan dilakukan pada pagi hari dan sore hari dengan jumlah pakan yang diberikan $5 \%$ dari bobot ikan dalam sekali pemberian pakan.Selama penelitian dilakukan pergantian air setiap 7 hari untuk menjaga kualitas air. Data panjang dan bobot ikan dianalisis menggunakan regresi dan dilakukan uji F. Hasil penelitian pertumbuhan panjang berat diperoleh nilai b berkisar 2,43-3,09. Pola pertumbuhan pada perlakuan $\mathrm{K}, \mathrm{L}, \mathrm{N}$, dan $\mathrm{O}$ yaitu alometrik negatif, sedangkan pola pertumbuhanpada perlakuan $\mathrm{M}$ yaitu isometrik. Hasil penelitian panjang berat diperoleh nilai $\mathrm{R}$ berkisar antara 0,86 - 0,96 atau mendekati nilai 1 , menunjukkan adanya hubungan yang erat antara panjang dan berat ikan Nila. Data pengukuran kualitas air selama penelitian diperoleh temperatur berkisar antara $25,0-26,9^{\circ} \mathrm{C}, \mathrm{pH}$ berkisar antara 5,00 - 6,95 dan oksigen terlarut berkisar antara 4,01 $-6,89 \mathrm{mg} / \mathrm{L}$.
\end{abstract}

Kata kunci $\quad$ : Berat; EZ-plus; Ikan Nila; dan Panjang

\begin{abstract}
One of the effort to optimize the growth of length and weight in the activity oF Tilapia growout is to improve the digestibility by giving EZ-plus enzyme into fish feed. This research aims to determine the relationship between length and weight of Oreochromis niloticus growth in various concentrations of enzymes the feed, and closeness between feeds that have been given enzymes with length and weight growth of fish. This research was conducted for 35 days in May-June 2017. The experiment conducted with Complete Randomized Design with 5 treatments as follows: control, $L(0,0125 \%), M(0,025 \%), N(0,05 \%)$ and $O(0,075 \%)$. Feeding done in the morning and afternoon with the amount $5 \%$ of fish weight in one feeding. During the research carried out water changes every 7 days to maintain water quality. The length - weight data were determined by linear regression analysis and $F$ test. Result of research of length and weight growth obtained value of $b$ ranged from 2,43-3,09. The growth pattern on the treatments of $K, L, N$ and $O$ are allometrik negative, while the growth pattern in $M$ treatment is isometric. Result of research length - weight growth obtained value of $R$ ranged from 0,86-0,96 or close value 1, meaning a close relationship between the length - weight of Tilapia fish.. Water quality measurement data during the research obtained temperatures ranged from $25,0-26,9^{\circ} \mathrm{C}$, the pH ranged from 5,00 to 6,95 and dissolved oxygen ranged from 4,01 to 6,89 $\mathrm{mg} / \mathrm{L}$.
\end{abstract}

Keywords: Weight; EZ-plus; Tilapia Fish; and Length

*)Penulis penanggungjawab

\section{PENDAHULUAN}

Indonesia memiliki perairan air tawar yang luas dengan berbagai jenis ikan air tawar. Perairan danau, waduk dan sungai di Indonesia tercatat seluas 14,6 juta Ha, sedangkan perairan rawa seluas 33,4 juta Ha. Dengan potensi perairan tawar yang besar tersebut, merupakan modal untuk pembangunan perikanan di Indonesia 
(Bambang, 2010).

Ikan Nila merupakan ikan domestik yang cukup banyak dibudidayakan di perairan Indonesia.Ikan ini mempunyai daging yang gurih dan enak. Ikan Nila mampu hidup dan berkembang biak secara baik pada perairan jernih dan berpasir serta berada pada kawasan bersuhu tinggi (Soeminto et al., 2000 dalam Kuncoro, 2013). Kegiatan pembesaran ikan yang tidak optimal akan merugikan bagi pembudidaya sendiri. Oleh karena itu diperlukan suatu usaha pengelolaan sumberdaya ikan yang memperhatikan keterkaitannya dengan aspek-aspek biologi agar stok ikan yang ada dalam kegiatan pembesaran dapat dikelola secara optimal untuk menambah nilai ekonomis bagi masyarakat yang melakukan kegiatan pembesaran.

Studi tentang hubungan panjang berat ikan Nila diperlukan dalam kegiatan pembesaran untuk mengoptimalkan pertumbuhan, dalam hal ini dengan pemberian pakan buatan yang telah ditambahkan suatu enzim pencernaan. Enzim pencernaan yang diberikan dengan dosis yang pas akan menghasilkan pertumbuhan yang optimal.

Tujuan dari penelitian ini adalah sebagai berikut:

1. Mengetahui hubungan antara pertumbuhan panjang dengan berat ikan nila pada berbagai konsentrasi enzim yang ditambahkan pada pakan.

2. Mengetahui pola dan keeratan hubungan antara pemberian pakan yang ditambah suplemen EZ-plus dengan pertambahan panjang dan berat ikan.

\section{MATERI DAN METODE PENELITIAN \\ Lokasi dan waktu penelitian}

Penelitianinidilakukan di Laboratorium Pengelolaan Sumberdaya Ikan dan Lingkungan FPIK Universitas Diponegoro.Sampelikan yang digunakandiperolehdariBalaiPembenihandanBudidayalkan Air Tawar (BPBIAT) Ambarawa, Semarang denganpanjangikanberukuran 70-90 mm dan bobot ikan berkisar antara $7-15$ gram dengankapasitasikannilasatu ekor ikan dalam satu akuarium dengan volume air 10 liter.Alat dan bahan yang digunakan dalam penelitian adalah sebagai berikut.

Alat

Alat yang digunakan dalam penelitian ini adalah akuarium dengan ukuran 30x20x20 cm untuk media pemeliharaan, Water QualityChecker (WQC) untuk mengukur kualitas perairan diantaranyapH, temperatur dan DO. Timbangan digital dengan ketelitain $0,01 \mathrm{gr}$ untuk mengukur bobot ikan, penggaris dengan ketelitian $1 \mathrm{~mm}$ untuk mengukur panjang ikan, botol dengan volume $250 \mathrm{~mL}$ untuk wadah enzim, alat tulis untuk mencatat, kamera untuk dokumentasi dan laptop untuk mengolah data.

\section{Bahan}

Bahan yang digunakan dalam penelitian ini adalah ikan Nila dan larutan enzim digunakan untuk penambahan ke dalam pakan.

\section{Metode}

Metode dalam penelitian ini menggunakan eksperimental dengan pengumpulan data yang dilakukan secara observasi langsung (Suharsimi, 1989 dalam Mujahir, 2016). Rancangan percobaan yang digunakan dalam penelitian ini berupa rancangan acak lengkap (RAL) dengan lima perlakuan dan tiga kali ulangan. Menurut Sudjana (2005) dalam Saputra (2014), rancangan acak lengkap digunakan pada penelitian yang bersifat homogen (perlakuan tunggal) dan perlakuan dikenakan sepenuhnya secara acak terhadap unit-unit eksperimen.Perlakuan yang digunakan adalah dengan menambahkan enzim pencernaan pada pakan ikan untuk membantu efisiensi pemanfaatan pakan dan meningkatkan pertumbuhan.Karena pada penelitian ini dilakukan perlakuan untuk memanipulasi objek penelitian disertai dengan adanya kontrol (Nazir, 2003). Dilakukan pengadaan ikan stok dengan ukuran yang sama, ikan stok diberi perlakuan yang sama dengan ikan uji dengan media yang berbeda dengan jumlah ikan stok dua ekor setiap perlakuan. Ikan stok berfungsi sebagai cadangan untuk menggantikan apabila ada ikan uji yang mati saat penelitian berlangsung. Selanjutnya penempatan akuarium percobaan dilakukan secara acak dengan menggunakan program Microsoft Office Excel. Tata letak rancangan pada pelaksanaan uji dapat dilihat pada Gambar 1. 


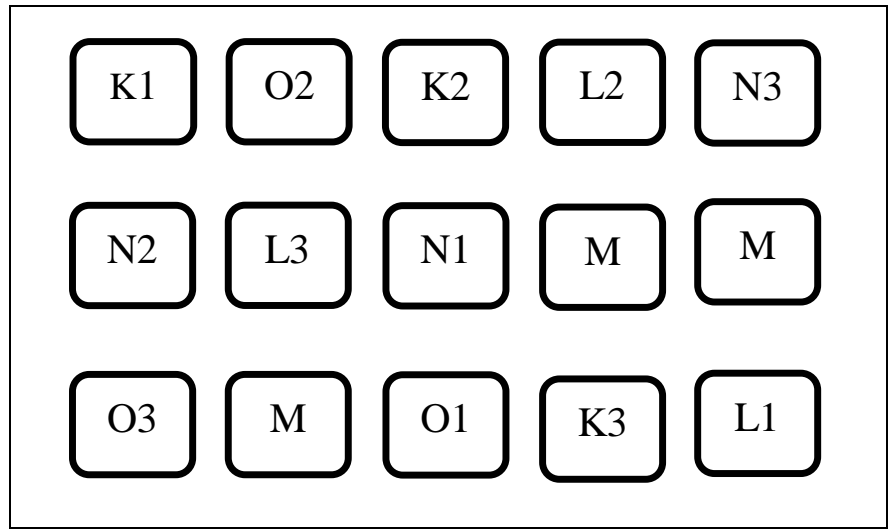

Gambar 1. Tata Letak Rancangan Media Penelitian

Pengukuran panjang ikan uji dilakukan menggunakan alat ukur mistar dengan ketelitian $0,1 \mathrm{~mm}$, sedangkan bobot ikan uji ditimbang menggunakan timbangan digital dengan ketelitian 0,01 gram.Pengukuran panjang total tubuh dan bobot ikan uji dilakukan setiap tujuh hari selama 35 hari. Ikan uji dengan label $\mathrm{K}$ merupakan ikan kontrol yang tidak ditambahkan enzim pada pakan, untuk ikan uji dengan label L, M, N dan O diberikan perlakuan berupa penambahan enzim berturut-turut sebesar $0,0125 \%, 0,025 \%, 0,05 \%$, dan $0,075 \%$ pada pakan. Pemberian pakan dilakukan sebanyak dua kali, pagi hari pada pukul 08.00 dan sore hari pada pukul 16.00 dengan jumlah pakan yang diberikan sebanyak 5\% dari bobot tubuh. Selama penelitian dilakukan penyiponan setiap seminggu sekali untuk menjaga agar kualitas air tetap layak sebagai media pemeliharaan ikan,

\section{Analisis data panjang - berat} berikut:

Rumus yang digunakan untuk menghitung hubungan panjang dan berat menurut Fauran (2009), sebagai

Kererangan :

$$
\boldsymbol{W}=\boldsymbol{a} \cdot \boldsymbol{L}^{\boldsymbol{b}}
$$
$\mathrm{W}$
a dan b
: Bobot ikan dalam gram
L
: Konstanta
: Panjang ikan dalammilimeter

Pola pertumbuhan pada ikan terdapat dua macam yaitu pertumbuhan isometrik $(b=3)$, apabila pertambahan panjang dan berat ikan seimbang dan pertumbuhan alometrik $(b>3$ atau $b<3), b>3$ menunjukkan ikan itu gemuk/ montok, dimana pertambahan berat lebih cepat dari pertambahan panjangnya, $b<3$ menunjukkan ikan dengan kategori kurus, dimana pertambahan panjangnya lebih cepat dari pertambahan berat (Fauran, 2009).

\section{HASIL DAN PEMBAHASAN \\ Pertumbuhan Bobot}

Data pertumbuhan bobot selama pemeliharaan diperoleh bobot rata-rata tertinggi pada perlakuan L sebesar 3,72 gr, sementara pertumbuhan bobot terendah diperoleh pada perlakuan O sebesar 2,01gr, sedangkan pada perlakuan K sebesar 2,12 gr, M sebesar 2,26 gr dan N sebesar 2,17 gr yang dapat dilihat pada Gambar 2.

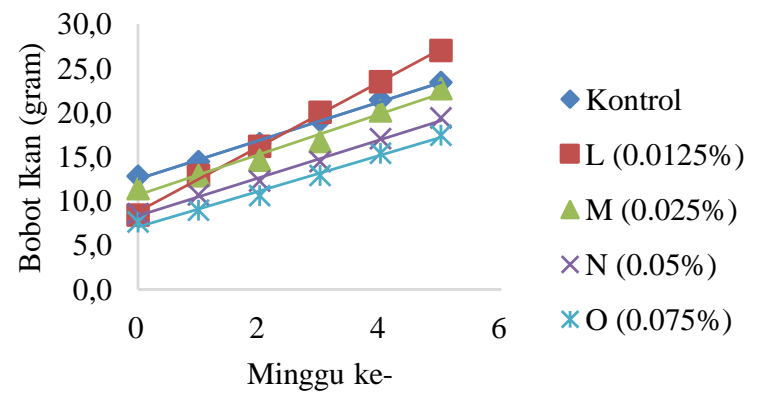

Gambar 2. Grafik Perkembangan Bobot Rata-rata Ikan Uji 
Berdasarkan pengamatan yang dilakukan setiap tujuh hari, dapat dilihat peningkatan pertumbuhan bobot ikan Nila selama masa pemeliharaan. Grafik menunjukkan perlakuan L terjadi penambahan bobot yang lebih tinggi sebesar 3,72 gr, dan yang paling rendah adalah perlakuan $\mathrm{O}(2,01 \mathrm{gr})$ sedangkan pertumbuhan bobot tertinggi ke dua, ke tiga dan ke empat berturut-turut adalah perlakuan $\mathrm{M}(2,26 \mathrm{gr}), \mathrm{N}(2,17 \mathrm{gr})$ dan $\mathrm{K}(2,12 \mathrm{gr})$. Grafik penambahan bobot selama pemeliharaan dapat dilihat pada Gambar 2. Dari hasil analisa uji F menunjukkan bahwa perlakuan tidak memberikan pengaruh terhadappertumbuhan bobot. Hal ini dilihat dari nilai F hitung $(1,308)<\mathrm{F}$ tabel $(4,066)$.

\section{Pertumbuhan Panjang}

Selama penelitian ikan Nila mengalami pertumbuhan panjang seiring dengan bertambahnya waktu pemeliharaan. Pertumbuhan panjang rata-rata selama penelitian diperoleh bahwa pertumbuhan panjang tertinggi pada perlakuan $\mathrm{L}$ sebesar $(8 \mathrm{~mm})$, sedangkan pertumbuhan panjang terendah pada perlakuan $\mathrm{M}$ sebesar $(4,5 \mathrm{~mm})$, kemudian pada perlakuan $\mathrm{O}, \mathrm{N}$, dan K berturut-turut sebesar $(5,7 \mathrm{~mm}),(6,1 \mathrm{~mm})$ dan $(4,7 \mathrm{~mm})$. Pertumbuhan ratarata ikan selama penelitian dapat dilihat pada Gambar 3.

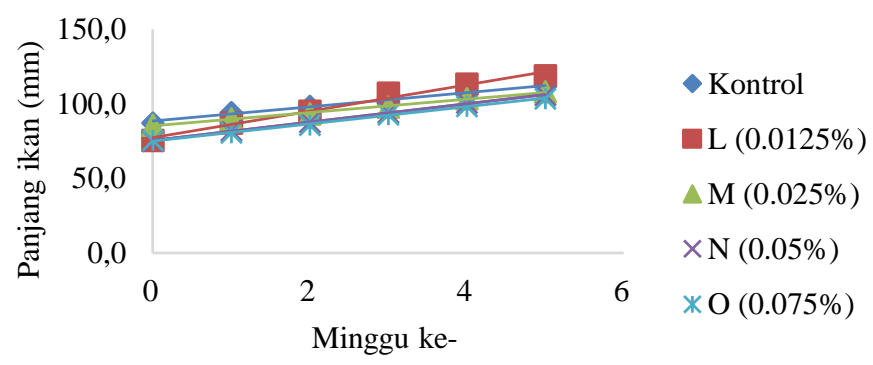

Gambar 3. Grafik Perkembangan Pertambahan Panjang Rata-Rata

Dari hasil analisis uji F menunjukkan bahwa perlakuan tidak memberikan pengaruh terhadap laju pertumbuhan panjang. Hal ini dapat dilihat dari F hitung $1,647<\mathrm{F}$ tabel 4,066

\section{Hubungan panjang dan berat}

Tabel 1. Hubungan Panjang Total dan Berat Ikan Nila (Oreochromis niloticus)

\begin{tabular}{cccccccc}
\hline \multirow{2}{*}{ Ikan Uji } & \multicolumn{6}{c}{ Parameter } \\
\cline { 2 - 7 } & $\mathrm{n}$ & $\mathrm{a}$ & $\mathrm{b}$ & $\left(\mathrm{R}^{2}\right)$ & $\mathrm{r}$ & $\mathrm{W}$ & Pola Pertumbuhan \\
\hline $\mathrm{K}$ & 3 & $1,86 \times 10^{-5}$ & 2,98 & 0,96 & 0,979 & $1,86 \times 10^{-5} \mathrm{~L}^{2,98}$ & Alometrik negatif \\
$\mathrm{L}$ & 3 & $2,37 \times 10^{-4}$ & 2,43 & 0,92 & 0,959 & $2,37 \times 10^{-4} \mathrm{~L}^{2,43}$ & Alometrik negatif \\
M & 3 & $1,17 \times 10^{-5}$ & 3,09 & 0,97 & 0,982 & $1,17 \times 10^{-5} \mathrm{~L}^{3,09}$ & Isometrik \\
$\mathrm{N}$ & 3 & $1,21 \times 10^{-4}$ & 2,56 & 0,96 & 0,979 & $1,21 \times 10^{-4} \mathrm{~L}^{2,56}$ & Alometrik negatif \\
$\mathrm{O}$ & 3 & $7,82 \times 10^{-5}$ & 2,65 & 0,86 & 0,928 & $7,82 \times 10^{-5} \mathrm{~L}^{2,65}$ & Alometrik negatif \\
\hline
\end{tabular}

Berdasarkan hasil penelitian yang telah dilakukan, diperoleh data panjang dan berat ikan Nila.Hal ini diperlukan untuk mengetahui adanya hubungan antara variabel panjang dan berat ikan Nila. Hasil perhitungan panjang berat dengan selang kepercayaan 95\%, pada kontrol diperoleh yaitu nilai a sebesar 0,00000186 dan nilai b sebesar 2,976. Persamaan hubungan panjang berat ikan Nila $\mathrm{W}=0,00000186 \mathrm{~L}^{2,9761}$. Nilai b yang diperoleh kurang dari 3, menunjukkan pertambahan panjang lebih cepat dari pertumbuhan bobot, sehingga termasuk dalam alometrik negatif.

Untuk hasil perhitungan panjang berat pada perlakuan L $(0,0125 \%)$ diperoleh yaitu nilai a sebesar 0,0000237 dan nilai b sebesar 2,431. Persamaan hubungan panjang berat ikan Nila $W=0,0000237 L^{2,4316}$. Nilai b yang diperoleh kurang dari 3, menunjukkan pertambahan panjang lebih cepat dibandingkan pertambahan bobot, sehingga termasuk dalam alometrik negatif. Hasil perhitungan panjang berat pada perlakuan $\mathrm{M}(0,025 \%)$ diperoleh nilai a sebesar 0,00000117 dan nilai b sebesar 3,091. persamaan hubungan panjang berat ikan $\mathrm{W}=$ $0,00000117 \mathrm{~L}^{3,0912}$. Nilai b yang diperoleh 3, menunjukkan pertambahan panjang selaras dengan pertambahan bobot, sehingga termasuk dalam isometrik.

Hasil perhitungan panjang berat pada perlakuan $\mathrm{N}(0,05 \%)$ diperoleh nilai a sebesar 0,0000121 dan nilai $\mathrm{b}$ sebesar 2,5613. Persamaan hubungan panjang berat ikan $\mathrm{W}=0,0000121 \mathrm{~L}^{2,5613}$. Nilai b yang diperoleh kurang dari 3, menunjukkan pertambahan panjang lebih cepat dari pertambahan bobotnya. Perhitungan panjang berat pada perlakuan $\mathrm{O}(0,075 \%)$, diperoleh nilai a sebesar 0,00000782 dan nilai b sebesar 2,651. persamaan hubungan panjang berat ikan $\mathrm{W}=0,00000782 \mathrm{~L}^{2,6513}$. Nilai b yang diperoleh kurang dari 3 , menunjukkan pertambahan panjang lebih cepat dari pertambahan bobotnya, sehingga termasuk alometrik negatif. 
Menurut penelitian Kuncoro (2013), pertumbuhan ikan Nila yang hidup diperairan Rawa Pening memiliki nilai b sebesar 2,9,sedangkan penelitian yang dilakukan oleh Muhotimah et al. (2013), ikan Nila hitam yang dipelihara dalam kolam budidaya memiliki persamaan hubungan panjang berat $\mathrm{W}=1,5268 \mathrm{~L}^{2,8117}$ dengan nilai $\mathrm{b}$ sebesar 2,81 yang artinya pola pertumbuhan kedua ikan tersebut adalah alometrik negatif atau pertumbuhan panjang lebih cepat dibandingkan dengan pertumbuhan bobot.Menurut Efendi (2003), bahwa pengaruh ukuran panjang dan bobot tubuh ikan sangat besar terhadap nilai b yang diperoleh sehingga secara tidak langsung faktor-faktor yang berpengaruh terhadap ukuran tubuh ikan akan mempengaruhi pola variasi dari nilai b.

Menurut penelitian Heti (2013), pada awal pertumbuhannya, pertumbuhan panjang lebih cepat dibandingkan pertambahan bobot, dan sebaliknya setelah ukuran dewasa pertambahan bobot lebih cepat dari pertambahan panjangnya.Perbedaan sifat pertumbuhan ini disebabkan oleh beberapa faktor diantaranya ketersediaan pakan, jenis kelamin, umur, sifat genetik, kualitas perairan, dan ketahanan terhadap penyakit. Hal ini diperkuat oleh Saputra (2013), perbedaan nilai b ini dapat disebabkan oleh faktor dalam seperti umur, jenis kelamin, sifat genetik, kemampuan memanfaatkan pakan dan ketahanan terhadap penyakit, dan faktor luar seperti ketersediaan makanan, temperatur air, dan lain-lain.

Untuk mengetahui apakah ada pengaruh yang signifikan pada perlakuan pemberian enzim dengan panjang dan berat diuji dengan analisis sidik ragam (uji F). Hasil dari analisis uji $\mathrm{F}$ antara pemberian enzim terhadap panjang ikan diperoleh $\mathrm{F}$ hitung $(1,64)<\mathrm{F}$ tabel $(3,48)$. Hal ini menunjukkan tidak adanya pengaruh yang signifikan antara perlakuan dengan pertumbuhan panjang. Pertumbuhan panjang rata-rata selama penelitian diperoleh bahwa pertumbuhan panjang tertinggi pada perlakuan L sebesar $8 \mathrm{~mm}$, sedangkan pertumbuhan panjang terendah pada perlakuan $\mathrm{M}$ sebesar 4,5mm, kemudian pada perlakuan $\mathrm{O}, \mathrm{N}$ dan $\mathrm{K}$ berturut-turut sebesar $5,7 \mathrm{~mm}, 6,1 \mathrm{~mm}$ dan $4,7 \mathrm{~mm}$.

Hasil dari analisis uji $\mathrm{F}$ antara pemberian enzim terhadap pertambahan bobot ikan diperoleh $\mathrm{F}$ hitung $(1,60)<\mathrm{F}$ tabel $(3,48)$. Hal ini menunjukkan bahwa perlakuan pemberian enzim terhadap pertambahan bobot tubuh tidak ada pengaruh yang signifikan. Pertumbuhan bobot selama pemeliharan diperoleh bobot rata-rata tertinggi pada perlakuan $\mathrm{L}$ sebesar 3,72 gr, sementara pertumbuhan bobot terendah diperoleh pada perlakuan $\mathrm{O}$ sebesar 2,01 gr. sedangkan perlakuan K sebesar 2,12 gr, M sebesar 2,26 gr dan N sebesar 2,17 gr.Disimpulkan bahwa pertumbuhan panjang mau pun berat ikan uji yang optimal terjadi pada perlakuan M $(0,025 \%)$ hal ini dikarenakan perumbuhan ikan uji pada perlakuan $\mathrm{M}$ mendapatkan hasil yang paling baik diantara ikan uji dengan perlakuan lainnya.

Pertumbuhan dapat dilihat dari perubahan bobot tubuh dan ukuran panjang total ikan nila. Semakin banyak makanan yang diserap oleh ikan pertumbuhan ikan semakin tinggi. Menurut Mulyadi et al. (2014), pertumbuhan merupakan perubahan ukuran ikan baik dalam berat, panjang maupun volume selama periode waktu tertentu yang disebabkan oleh perubahan jaringan akibat pembelahan sel otot dan tulang yang merupakan bagian terbesar dari tubuh ikan sehingga menyebabkan penambahan bobot ikan.

Grafik hubungan panjang berat selama penelitian berdasarkan perlakuan tersaji pada Gambar 5.
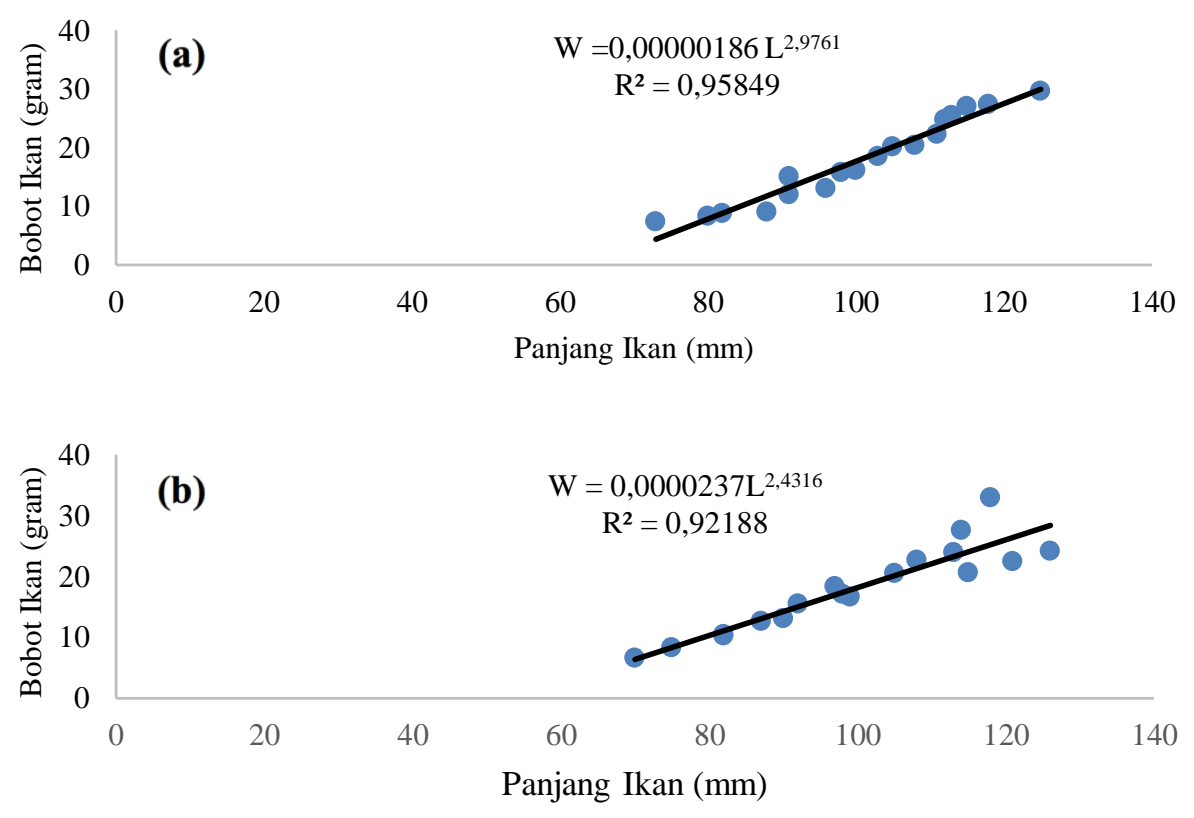

${ }^{\circledR}$ Copyright by Management of Aquatic Resources (MAQUARES) 

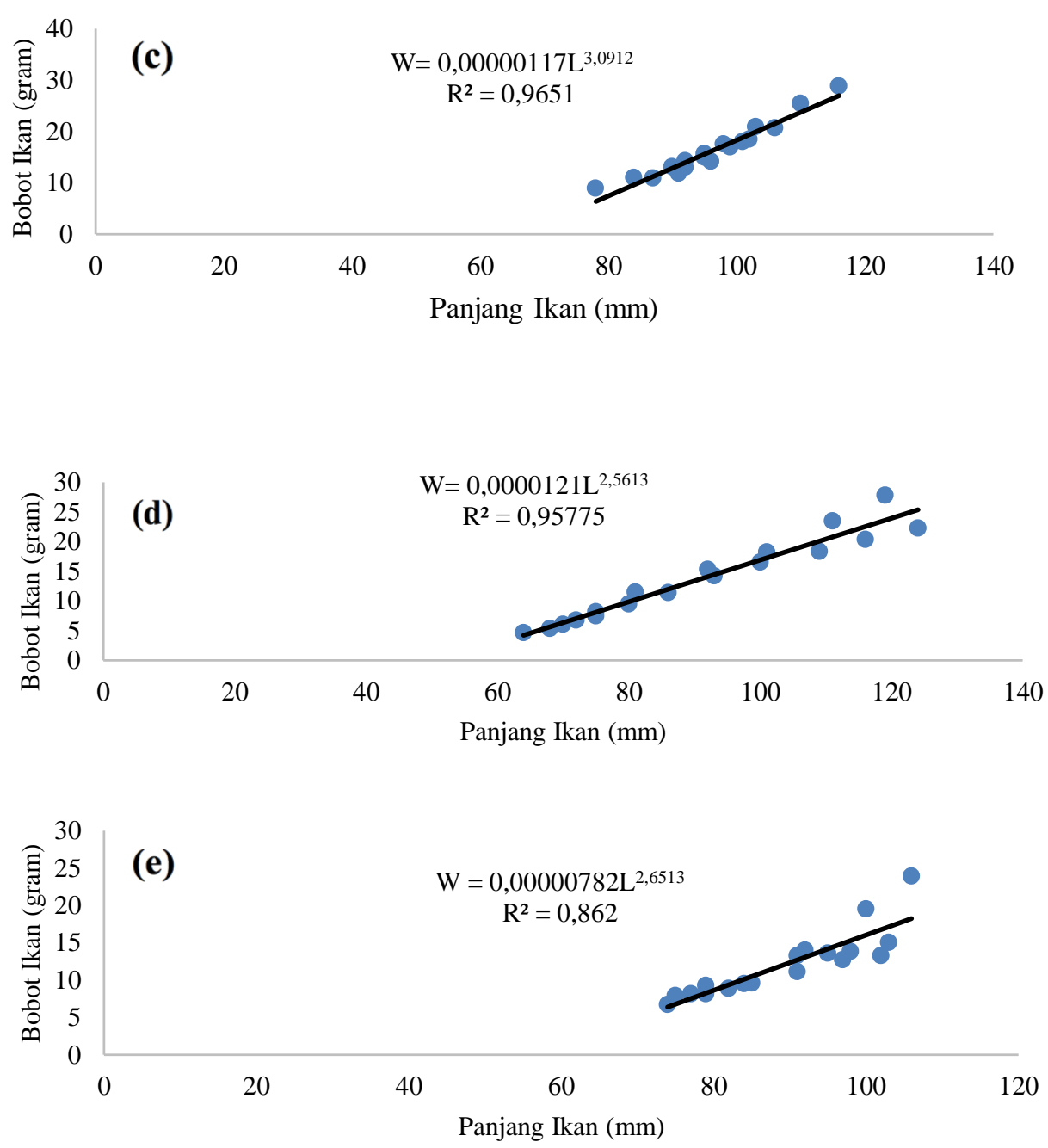

Gambar 5.Hubungan Panjang Berat (a) kontrol, (b) perlakuan L,(c) perlakuan M, (d) perlakuan $\mathrm{N}$ dan (e) perlakuan $\mathrm{O}$.

\section{Kualitas Air}

Kualitas air merupakan salah satu hal yang perlu diperhatikan dalam kegiatan budidaya karena sangat berpengaruh terhadap perkembangan dan pertumbuhan ikan. Kunci keberhasilan suatu budidaya antara lain dipengaruhi oleh kemampuan mengendalikan faktor lingkungan. Faktor lingkungan yang dapat mempengaruhi kehidupan adalah kualitas air seperti temperatur, oksigen terlarut (DO), dan derajat keasaman (pH). Menurut Mas'ud (2014), Walaupun ikan nila merupakan jenis ikan yang memiliki toleransi tinggi terhadap perubahan lingkungan perairan, namun kualitas air dalam wadah budidaya harus tetap dikelola dengan baik agar pertumbuhannya tetap optimal. Dari hasil pengukuran temperatur, oksigen terlarut (DO) dan derajat keasaman $(\mathrm{pH})$ didapatkan masih dalam ambang batas untuk kegiatan budidaya. Nilai temperatur didapatkan berkisar $25^{\circ} \mathrm{C}$ $-27^{\circ} \mathrm{C}$, hal ini diperkuat oleh Mas'ud (2014), kisaran suhu yang baik untuk budidaya ikan Nila adalah 25 $30^{\circ} \mathrm{C}$. Untuk kadar oksigen terlarut (DO) yang didapatkan hasil pengukuran berkisar 4,0 - 6,8 mg/L sedangkan untuk derajat keasaman $(\mathrm{pH})$ didapatkan hasil 5,0 - 6,9. Hal ini diperkuat oleh Ghufran dan Tancung (2007), menyatakan bahwa beberapa jenis ikan mampu bertahan hidup pada perairan dengan konsentrasi oksigen terlarut sebesar $3 \mathrm{mg} / \mathrm{L}$, namun konsentrasi oksigen terlarut yang baik untuk hidup ikan adalah $5 \mathrm{mg} / \mathrm{L}$, dalam budidaya pada pH 5 masih dapat ditolerir oleh ikan tetapi pertumbuhan ikan akan terhambat.

\section{KESIMPULAN}

Kesimpulan yang diperoleh dari penelitian Hubungan Panjang dan Berat Ikan Nila (Oreochromis niloticus) dalam Pembesaran dengan Penambahan Enzim EZ-Plus (Skala Laboratorium) adalah sebagai berikut:

1. Hubungan antara pertumbuhan panjang dengan berat pada ikan uji menghasilkan sifat pertumbuhan alometrik negatif dan isometrik. 
2. Perlakuan penambahan enzim terhadap pertumbuhan panjang dan berat menunjukkan tidak adanya pengaruh.

\section{UCAPAN TERIMAKASIH}

Penulis mengucapkan terimakasih kepada ibu Churun A'in S.Pi, M.Si dan bapak Wiwiet Teguh T., S.Pi, M.Si yang telah memberikan masukan dalam pembuatan jurnal ini.

\section{DAFTAR PUSTAKA}

Bambang, C. 2010. Budidaya Ikan Air Tawar: Ikan Gurami, Ikan Nila, Ikan Mas. Yogyakarta: Kanisius.

Effendi, H. 2003. Telaah Kualitas Air Bagi Pengelolaan Sumber Daya dan Lingkungan Perairan. Kanisius. Yogyakarta.

Fauran, A. 2009. Aspek Biologi Pertumbuhan, Reproduksi dan Kebiasaan Makan Ikan Selar Kuning (Caranx leptolepsis). Departemen Sumberdaya Perikanan Fakultas Perikanan dan Ilmu Kelautan Institut Pertanian Bogor. Bogor. 40(1) : 18-24.

Heti. 2013. Penambahan Senyawa Taurin pada Pakan Alami Bagi Pertumbuhan Juvenile Ikan Nila (Oreochromis niloticus). Jurusan Biologi. Fakultas Matematika dan Ilmu Pengetahuan Alam. Universitas Lampung. Bandar Lampung. SKRIPSI.

Kuncoro, M. D. 2013. Aspek Reproduksi Ikan Nila (Oreochromis niloticus) di Perairan Rawa Pening Kabupaten Semarang.Fakultas Perikanan dan Ilmu Kelautan. Universitas Diponegoro. SKRIPSI.

Mas'ud, F. 2014. Pengaruh Kualitas Air Terhadap Pertumbuhan Ikan Nila (Oreochromis sp.) di Kolam Beton dan Terpal.ProgramStudi manajemen Sumberdaya Perairan. Fakultas Perikanan. Universitas Islam Lamongan. 16(1): 1-21.

Muhotimah, B. Triyatmo, S. B. Priyono, dan T. Kuswoyo. 2013. Analisis Morfometrik dan MeristikNila (Oreochromis sp.) Strain Larasati F5 dan Tetuanya. Jurusan Perikanan. Fakultas Pertanian. Universitas Gajah Mada. Jurnal Perikanan 15(1) : 42-53.

Mujahir.2016. Rekayasa Nutrisi pada Pakan Buatan Diperkaya dengan Probiotik Herbal Terhadap Pertumbuhan Berat Mutlak Benih Ikan Nila (Oreochromis niloticus).Program Studi Budidaya perairan. Jurusan Perikanan. Fakultas Pertanian. Universitas Dr. Soetomo. 13(2) : 67-70.

Mulyadi, E. 2014. Pengantar Akuakultur. Penebar Swadaya. Jakarta. 188 Halaman.

Saputra, A. 2014. Aplikasi Penggunaan Enzim Pencernaan dengan Dosis yang Berbeda pada Pakan Terhadap Pertumbuhan dan Efisiensi Pemanfaatan pakan Benih Ikan Gurami batanghari (Osphronemus gouramy). Fakultas Perikanan. Universitas PGRI Palembang. 2(1) : 183-193.

Ghufran. H. M, Kordi K, dan Andi B.T. 2007. Pengelolaan Kualitas Air dalam Budidaya Perairan. Jakarta: Rineka Cipta. 